$$
\begin{array}{ll}
\text { Volume } & : 05 \\
\text { Nomor } & : 02 \\
\text { Bulan } & : \text { Mei } \\
\text { Tahun } & : 2019 \\
\text { http } & : \text { //ejurnal.pps.ung.ac.id/index.php/AKSARA/index }
\end{array}
$$

\title{
UPAYA MENINGKATKAN KEMAMPUAN MEMBACA PERMULAAN PADA SISWA KELAS 1 SDN 05 WANGGARASI TAHUN 2014/2015 MELALUI MEDIA GAMBAR
}

\author{
Djuita Kadir \\ SDN 05 Wanggarasi \\ djuitakadir@gmail.com
}

Received: 29 Februari 2019; Revised: 12 April 2019; Accepted: 15 April 2019

\begin{abstract}
ABSTRAK
Penelitian ini terdiri dari dua siklus. Tiap siklus dilaksanakan dengan tahapan sebagai berikut: (1) perencanaan, (2) pelaksanaan, (3) observasi, dan (4) refleksi. Penggunaan media gambar pada pelajaran Bahasa Indonesia khususnya kelas I SDN 05 Wanggarasi dalam kemampuan membaca permulaan, pada pelaksanaan siklus I menunjukan bahwa siswa masih kurang memiliki keberanian untuk tampil di depan kelas dan siswa pasif dalam pembelajaran sehingga kemampuan membaca siswa belum meningkat. Pada pelaksanaan pembelajaran siklus II, aktivitas belajar siswa menunjukkan hasil yang sangat baik. Sebagian besar siswa telah memiliki keberanian untuk tampil di depan kelas, serta menyimpulkan hasil kegiatan secara lisan. Untuk hasil membaca permulaan sudah terlihat peningkatan dari segi membacanya sesuai dengan lafal, ketepatan. kejelasan suara dan intonasi. Hasil penelitian ini menunjukkan bahwa pelaksanaan pembelajaran membaca permulaan melalui media gambar dapat meningkatkan hasil membaca permulaan siswa. Hal tersebut ditunjukkan pada pelaksanaan siklus I masih ada 6 orang atau $42,86 \%$ yang tuntas dan siswa yang tidak tuntas sebanyak 8 orang atau $57,14 \%$, sedangkan hasil pelaksanaan Siklus II terjadi peningkatan yaitu siswa yang tuntas sudah mencapai $85,71 \%$ atau 12 orang. Hal tersebut menunjukkan bahwa penggunaan media gambar pada pelajaran Bahasa Indonesia dapat meningkatkan kemampuan siswa kelas I SDN 05 Wanggarasi Tahun 2014/2015 dalam membaca permulaan.
\end{abstract}

Kata kunci : Membaca permulaan, Media Gambar

\section{PENDAHULUAN}

Membaca bagi manusia sebenarnya merupakan kebutuhan mendasar seperti kebutuhan manusia akan makan, pakaian, dan lain sebagainya. Membaca merupakan suatu keterampilan berbahasa yang sangat penting peranannya dalam kehidupan. Membaca mempunyai peranan penting dalam melahirkan generasi penerus bangsa yang cerdas, kreatif, dan kritis. Dengan membaca seseorang mendapat pengetahuan dan informasi dari berbagai penjuru dunia.

Pada dasarnya kemampuan dan keterampilan membaca menjadi suatu kebutuhan yang harus dipenuhi. Sehingga kemampuan membaca harus dilatih sejak dini. Kegiatan membaca permulaan dimulai dari taman kanak - kanak atau sekolah dasar tingkat awal. Namun pada kenyataannya kegiatan membaca kurang disukai anak - anak khususnya siswa sekolah dasar yang pada dasarnya masih suka bermain, belum fokus dan memusatkan perhatian. Dalam satu kelas saja dapat dihitung siswa yang gemar membaca tanpa dipaksa dari pihak lain seperti orang tua atau guru. Apabila seorang siswa belum bisa membaca, siswa tersebut akan kesulitan dalam memahami pelajaran khususnya dalam mata pelajaran bahasa Indonesia. Di samping itu, kegiatan membaca tidak hanya sekedar membaca sekilas saja, tetapi juga dapat memahami isi yang terkandung di dalam bahan bacaan yang dibaca. 


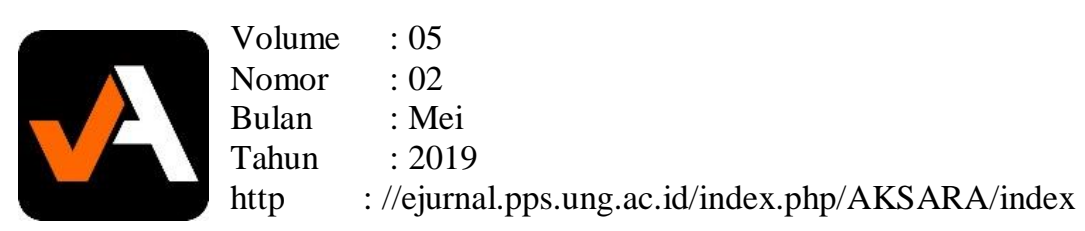

Didalam keterampilan membaca antara lain mempelajari tentang membaca permulaan. "Membaca permulaan adalah pengajaran membaca awal yang diberikan kepada siswa kelas I dengan tujuan agar siswa terampil membaca serta mengembangkan pengetahuan bahasa dan keterampilan berbahasa guna menghadapi kelas berikutnya". Kemampuan membaca yang diperolah pada membaca permulaan sangat berpengaruh pada kemampuan membaca lanjut. Sebagai kemampuan yang mendasari kemampuian berikutnya. Kemampuan membaca permulaan memerlukan perhatian guru sebab jika dasarnya tidak kuat,tahap berikutnya akan mengalami kesulitan.

Keterampilan membaca permulaan sebagai salah satu keterampilan berbahasa yang perlu dimiliki oleh siswa Sekolah Dasar kelas I. Peranan pengajaran bahasa Indonesia khususnya pengajaran membaca di Sekolah Dasar menjadi sangat penting karena keterampilan ini secara langsung berkaitan dengan seluruh proses belajar siswa di Sekolah Dasar. Keberhasilan siswa dalam proses belajar mengajar di sekolah sangat ditentukan oleh penguasaan keterampilan membaca mereka. Siswa yang tidak terampil membaca dengan baik akan mengalami kesulitan dalam mengikuti kegiatan pembelajaran.

Dalam hal ini media akan membantu siswa dalam memahami pelajaran membaca permulaan. Dalam proses belajar mengajar kehadiran media cukup penting khususnya media gambar. Dengan media gambar siswa lebih menyukainya apalagi gambar dibuat dan disajikan sesuai dengan persyaratan yang baik, sudah tentu akan menambah semangat siswa dalam mengikuti proses pembelajaran, terlebih lagi dalam pelajaran membaca permulaan di kelas I. Melalui media gambar, siswa termotivasi untuk belajar dan terus menerus belajar, sehingga rasa keingintahuan siswa besar dan mendorong siswa selalu belajar membaca dan kode pikirannya siswa semakin terampil membaca permulaan di kelas I.

\section{TINJAUAN PUSTAKA \\ Membaca Permulaan}

Menurut Darmiyati dan Budiasih (2001: 57) pembelajaran membaca dikelas I dan kelas II merupakan pembelajaran membaca tahap awal. Kemampuan membaca diperoleh siswa di kelas I dan kelas II tersebut akan menjadi dasar pembelajarn membaca di kelas berikutnya. Menurut Santosa (2007: 3,19) pembelajaran membaca di sekolah dasar terdiri atas dua bagian yakni membaca permulaan yang dilaksanakan di kelas I dan II. Melalui membaca permulaan ini, diharapkan siswa mampu mengenal huruf, suku kata, kata, kalimat dan mampu membaca dalam berbagai konteks. Sedangkan membaca lanjut dilaksanakan di kelas tinggi atau di kelas III, IV, V dan VI.

Menurut Tarigan (1997: 5.33) pembelajaran membaca permulaan bagi siswa kelas I SD dapat dibedakan ke dalam dua tahap yakni belajar membaca tanpa buku diberikan pada awal awal anak memasuki sekolah. Pembelajaran membaca permulaan dengan menggunakan buku dimulai setelah murid - murid mengenal huruf - huruf dengan baik kemudian diperkenalkan dengan lambang-lambang tulisan yang tertulis dalam buku. Sedangkan menurut Darmiyati dan Budiasih (2001: 58) membaca permulaan diberikan secara bertahap, yakni pramembaca dan membaca. Pada tahap pramembaca, kepada siswa diajarkan: (1) sikap duduk yang baik pada waktu membaca; (2) cara meletakkan buku di meja; (3) cara memegang buku; (4) cara membuka dan membalik halaman buku; dan (5) melihat dan memperhatikan tulisan. Pembelajaran membaca permulaan dititik beratkan pada aspek - aspek yang bersifat teknis seperti ketepatan menyuarakan tulisan, lafal dan intonasi yang wajar, kelancaran dan kejelasan suara.

Berdasarkan beberapa uraian di atas dapat disimpulkan membaca permulaan adalah membaca yang dilaksanakan di kelas I dan II, dimulai dengan mengenalkan huruf - huruf dan 


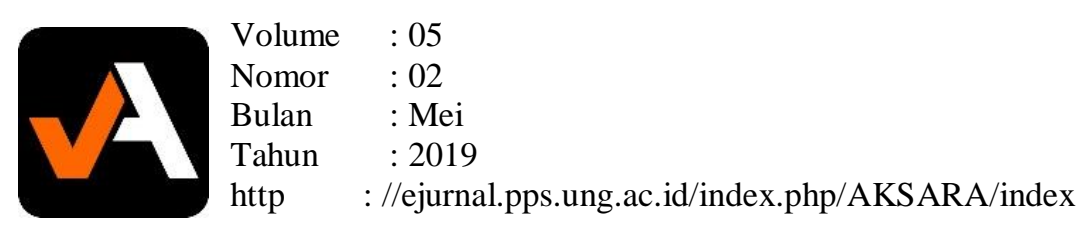

lambang - lambang tulisan yang menitik beratkan pada aspek ketepatan menyuarakan tulisan, lafal dan intonasi yang wajar, kelancaran dan kejelasan suara.

Menurut Darmiyati dan Budiasih (2001: 57) kemampuan membaca yang diperoleh pada membaca permulaan akan sangat berpengaruh terhadap kemampuan membaca lanjut. Sebagai kemampuan yang mendasari kemampuan berikutnya maka kemampuan membaca permulaan benar-benar memerlukan perhatian guru, membaca permulaan di kelas I merupakan pondasi bagi pengajaran selanjutnya. Sebagai pondasi haruslah kuat dan kokoh, oleh karena itu harus dilayani dan dilaksanakan secara berdaya guna dan sungguh-sungguh. Kesabaran dan ketelitian sangat diperlukan dalam melatih dan membimbing serta mengarahkan siswa demi tercapainya tujuan yang diharapkan. Menurut Rukayah (2004: 14) anak atau siswa dikatakan berkemampuan membaca permulaan jika dia dapat membaca dengan lafal dan intonasi yang jelas, benar dan wajar, serta lancar dalam membaca dan memperhatikantanda baca.

\section{Media Gambar Berseri}

Media gambar merupakan salah satu jenis media visual atau grafis. Sesuai dengan pendapat Arief S. Sadiman, dkk (2007: 29) yang menyatakan bahwa media grafis meliputi gambar / foto, sketsa, diagram, bagan, grafik, kartun, poster, peta dan globe. Media gambar / foto sangat umum digunakan dalam pembelajaran karena kepraktisan dan kemudahannya dalam menggunakan. Walaupun telah banyak digunakan dalam pembelajaran, akan tetapi media gambar tetap mampu menyita perhatian siswa dan mampu memberikan visualisasi yang lebih jelas mengenai konsep yang akan diberikan. Media gambar adalah penyajian visual dua dimensi yang memanfaatkan rancangan gambar sebagai sarana pertimbangan mengenai kehidupan sehari - hari, misalnya menyangkut manusia, peristiwa, benda - benda, dan tempat. Menurut Nana Sudjana dan Ahmad Rivai dalam Azhar Arsyad (2007:125) mengemukakan bahwa media gambar adalah media yang mengombinasikan fakta dan gagasan secara jelas dan kuat melalui kombinasi dan pengungkapan kata - kata dengan gambar. Menurut Nana Sudjana dan Ahmad Rivai dalam Azhar Arsyad (2007:125) mengemukakan bahwa media gambar adalah media yang mengombinasikan fakta dan gagasan secara jelas dan kuat melalui kombinasi dan pengungkapan kata - kata dengan gambar. Sedangkan Oemar Hamalik dalam Azhar Arsyad (2007: 113) "Gambar adalah media yang paling umum dipakai yang dapat dimengerti dan dinikmati di mana -mana".

Dari beberapa pendapat di atas, penulis dapat mengambil keputusan bahwa media gambar adalah media yang memvisualisasikan konsep ke dalam sebuah gambar dan menampakkan benda atau peristiwa, umum digunakan di mana - mana, dapat dimengerti dan dinikmati dalam pembelajaran, untuk mengatasi kesulitan mendapatkan dan menampilkan benda aslinyadi dalam ruangan kelas. Dengan media gambar akan memperjelas konsep dan instruksi yang dikomunikasikan guru, sehingga siswa lebih mudah mengerti dan menyerap informasi atau pengetahuan yang disampaikan.

\section{METODE PENELITIAN}

Penelitian ini dilaksanakan pada siswa kelas V SDN 05 Wanggrasi kecamatan Wanggarasi Kabupaten Pohuwato Tahun 2014/2015 yang berjumlah 14 orang terdiri dari 7 orang laki -laki dan 7 orang perempuan.

Untuk memudahkan penulis di dalam melakukan penelitian, maka dirancang dalam 2 siklus. Setiap siklus terdiri dari 4 tahap menggunakan empat langkah, yaitu: pengembangan plan (perencanaan), act (tindakan), observer (pengamatan) dan evaluation (evaluasi), serta reflect (perenungan). Penyusunan tiap tahapan pada tiap siklus dirancang sesuai dengan yang akan dicapai. 


$$
\begin{array}{ll}
\text { Volume } & : 05 \\
\text { Nomor } & : 02 \\
\text { Bulan } & : \text { Mei } \\
\text { Tahun } & : 2019 \\
\text { http } & : \text { //ejurnal.pps.ung.ac.id/index.php/AKSARA/index }
\end{array}
$$

\section{Sumber Data dan Metode Pengambilan Data}

a. Sumber data: sumber data dalam penelitian ini adalah siswa dan guru sebagai anggota peneliti

b. Cara Pengambilan Data

$\checkmark$ Data hasil observasi kegiatan guru dan kegiatan siswa

$\checkmark$ Data hasil belajar siswa dengan kriteria penilaian

\begin{tabular}{|l|l|l|l|l|l|}
\hline \multirow{2}{*}{ Siswa } & \multicolumn{4}{l|}{ Aspek Penilaian } \\
\cline { 2 - 6 } & Lafal & Kelancaran & Kejelasan & Intonasi & Jumlah \\
\hline $1 \ldots \ldots \ldots \ldots \ldots . . \ldots \ldots \ldots \ldots \ldots$ & & & & & \\
\hline $2 \ldots \ldots \ldots \ldots \ldots \ldots$ & & & & & \\
\hline
\end{tabular}

\section{Indikator Keberhasilan}

Yang menjadi indikator keberhasilan adalah jika hasil belajar ada peningkatan dari masingmasing tahap, yaitu :

a. Siswa mampu mendeskripsikan gambar, dan minimal $60 \%$ hasil membaca permulaan siswa menunjukkan peningkatan

b. Hasil yang dicapai siswa mengalami peningkatan dan telah mencapai KKM 60

\section{HASIL PENELITIAN DAN PEMBAHASAN}

\section{Hasil Penelitian Siklus I}

Pelaksanaan tindakan dalam penelitian adalah dua siklus. Siklus pertama terdiri dari dua pertemuan dan siklus dua juga dua pertemuan. Masing - masing pertemuan dilaksanakan selama dua jam pelajaran yang tiap jam terdiri 35 menit.

\section{Tahap Perencanaan Tindakan}

Tahap perencanaan dimulai dengan tahap koordinasi. Pada tahap koordinasi ini peneliti melakukan koordinasi dengan guru kelas. Koordinasi meliputi pembagian tugas, penentuan jadwal diskusi dan jadwal kerja

\section{Pelaksanaan Tindakan}

Pelaksanaan tindakan siklus I ini guru kelas bertindak sebagai pemimpin jalannya kegiatan. Pelaksanaan pembelajaran dilakukan oleh peneliti dan seorang observer. Pembelajaran yang disusun untuk siklus I dengan menggunakan media gambar dilaksanakan dalam dua kali pertemuan.

a. Pertemuan Pertama

$\checkmark$ Urutan pelaksanaan tindakan siklus I pertemuan pertama adalah sebagai berikut :

$\checkmark$ Mengawali pelajaran dengan berdoa setelah itu mengkondisikan kelas.

$\checkmark$ Siswa dan peneliti bertanya jawab tentang keadaan kelas I pada saat itu. Dengan keingintahuan pengetahuan dapat berkembang dan agar siswa dapat menemukan jawabannya sendiri.

$\checkmark$ Menyampaikan tujuan pembelajaran yang akan dicapai.

$\checkmark$ Menunjukkan gambar seri dan memberi contoh kepada siswa, siswa diminta menunjukkan gambar, dan minta maju ke depan untuk menunjukkan gambar sesuai deskripsi guru.

$\checkmark$ Siswa diminta membacakan nama gambar sesuai dengan gambar yang sudah ada.

$\checkmark$ Menunjukkan gambar, siswa diminta mengamati gambar, kemudian siswa diminta mendeskripsikan atau menjelaskan isi pada gambar.

$\checkmark$ Siswa diminta maju ke depan untuk memilih kartu kalimat yang sesuai dengan gambar tersebut. 


$$
\begin{array}{ll}
\text { Volume } & : 05 \\
\text { Nomor } & : 02 \\
\text { Bulan } & : \text { Mei } \\
\text { Tahun } & : 2019 \\
\text { http } & \text { ://ejurnal.pps.ung.ac.id/index.php/AKSARA/index }
\end{array}
$$

Siswa diminta menunjukkan kartu kalimat yang sesuai dengan gambar yang sudah disediakan.

$\checkmark$ Siswa diminta membaca kalimat yang sesuai dengan gambar.

b.Pertemuan kedua

$\checkmark$ Mengawali pelajaran dengan berdoa setelah itu mengkondisikan siswa.

$\checkmark$ Siswa dan peneliti bertanya jawab tentang kegiatan sebelum berangkat sekolah.

$\checkmark$ Menyampaikan tujuan pembelajaran yang akan dicapai.।

$\checkmark$ Salah satu siswa menceritakan kegiatan sebelum berangkat sekolah.

$\checkmark$ Siswa diminta mengamati gambar dengan teman sebangkunya untuk menjelaskan isi pada gambar tersebut.

$\checkmark$ Masing - masing siswa diberi tugas untuk menjelaskan isi pada gambar tersebut.

$\checkmark$ Selama proses pembelajaran guru mengamati setiap kegiatan siswa. Mengawasi siapa saja yang tidak mengerjakan dan siapa saja yang aktif dalam proses pembelajaran. Penilaian ini diperlukan untuk mengetahui apakah siswa benar - benar belajar atau tidak.

$\checkmark$ Akhir proses pembelajaran guru memberikan kesempatan kepada siswa untuk mengingat kembali apa yang telah dipelajarinya. Biarkan secara bebas siswa menafsirkan pengalamannya sendiri, sehingga ia dapat menyimpulkan tentang pengalamannya.

\section{Observasi}

Selama pelaksanaan pembelajaran peneliti bekerja sama dengan guru kelas untuk mengamati jalannya pembelajaran. Pada siklus I dengan panduan lembar observasi. Dari kegiatan observasi tersebut diperoleh gambaran tentang jalannya kegiatan belajar mengajar yang secara garis besar sebagai berikut :

\section{Bagi Guru}

(1). Kurang memberikan informasi secara tepat.

(2). Kurang memberikan motivasi siswa secara individu.

(3). Kurang perhatian terhadap siswa.

(4). Kurang mampu mengkondisikan siswa ke arah pembelajaran yang kondusif.

Bagi Siswa

(1). Siswa kurang memperhatikan penjelasan materi yang diberikan oleh guru.

(2). Siswa tidak tertarik terhadap apersepsi yang diberikan oleh guru.

(3). Rasa ingin tahu dan keberanian siswa masih rendah

\section{$\underline{\text { Refleksi }}$}

Berdasarkan hasil pengamatan dan hasil membaca permulaan siswa, guru, dan peneliti berdiskusi dan melakukan refleksi sebagai berikut :

$\checkmark$ Untuk mendorong keberanian siswa merespons stimulus guru, guru perlu membuat interaksi siswa dalam pembelajaran yang lebih beragam. Perbaikannya pada siklus II adalah guru lebih menciptakan suasana yang lebih menarik dalam pembelajaran untuk memberikan suasana belajar yang baru bagi siswa.

$\checkmark$ Untuk hasil membaca permulaan sudah terlihat peningkatan dari segi membacanya sesuai dengan lafal, ketepatan. kejelasan suara dan intonasi.

$\checkmark$ Mendatangkan buku - buku dari sumber lain pada siklus selanjutnya.

\section{Tabel 1}

Data Nilai Pada Tes Siklus I 


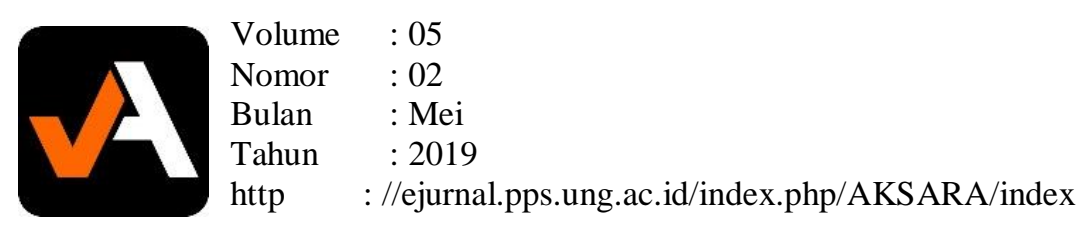

\begin{tabular}{|l|l|l|l|l|l|}
\hline \multirow{2}{*}{ No } & \multirow{2}{*}{ Nama Siswa } & Perolehan Nilai & \multirow{2}{*}{ Keterangan } \\
\cline { 3 - 5 } & & Pert. 1 & Pert. 2 & Rata-rata & \\
\hline 1 & Abd. Rahman Yusuf & 40 & 60 & 55 & TT \\
\hline 2 & Aryo Tangahu & 50 & 55 & 52,5 & TT \\
\hline 3 & Febriyati Ibrahim & 60 & 60 & 60 & T \\
\hline 4 & Moh.Agung Botutihe & 45 & 50 & 47,5 & TT \\
\hline 5 & Moh.Dardha Lasori & 50 & 55 & 52,5 & TT \\
\hline 6 & Refli Husain & 50 & 50 & 50 & TT \\
\hline 7 & Adelin Batanga & 40 & 50 & 45 & TT \\
\hline 8 & Anastasya Febiyani & 60 & 60 & 60 & T \\
\hline 9 & Apriyanti & 50 & 70 & 60 & T \\
\hline 10 & Rahma Djau & 40 & 60 & 50 & TT \\
\hline 11 & Siti Fadilah Djau & 80 & 80 & 80 & T \\
\hline 12 & Ahmad Thalib & 70 & 70 & 70 & T \\
\hline 13 & Agung Tangahu & 40 & 70 & 55 & T \\
\hline 14 & Geplin Haleda & 50 & 60 & 55 & TT \\
\hline Jumlah & 805 & 870 & 837,5 & \\
\hline Rata - rata & 57,5 & 62,14 & 59,82 & \\
\hline Keterangan & Jumlah & & Prosentase & \\
\hline Tuntas & 6 & 42,86 & \\
\hline Tidak Tuntas & 8 & 57,14 & \\
\hline
\end{tabular}

Dari data tersebut dapat dipahami bahwa setelah melaksanakan siklus I, siswa yang tuntas sebanyak 6 orang atau 42,86\% dan siswa yang tidak tuntas sebanyak 8 orang atau 57,14\%

\section{Hasil Penelitian Siklus II}

Dalam tahapan siklus I terdiri dari tahap perencanaan, pelaksanaan, pengamatan, dan refleksi. Tahap Perencanaan Tindakan

Peneliti dan guru mendiskusikan rancangan tindakan yang akan dilaksanakan dalam proses penelitian selanjutnya. Rancangan kegiatan dalam siklus II ini meliputi pembuatan rencana pembelajaran membaca permulaan dengan media gambar yang lebih bervariasi dari siklus yang sebelumnya.

\section{Pelaksanaan Tindakan}

Pelaksanaan tindakan siklus II ini guru kelas bertindak sebagai pemimpin jalannya kegiatan. Pelaksanaan pembelajaran diamati oleh seorang observer. Pembelajaran yang disusun pada siklus II dengan menggunakan media gambar dilaksanakan dalam dua kali pertemuan.

a. Pertemuan Pertama

$\checkmark$ Mengawali pelajaran dengan berdoa setelah itu mengkondisikan kelas.

$\checkmark$ Siswa dan guru bertanya jawab tentang kegiatan siswa.

$\checkmark$ Menyampaikan tujuan pembelajaran yang akan dicapai

$\checkmark$ Menunjukkan gambar.

$\checkmark$ Membagi kelompok dan tiap - tiap kelompok diminta untuk mengurutkan gambar terlebih dulu, kemudian siswa dari tiap - tiap kelompok diminta mendeskripsikan gambar sesuai urutannya.

$\checkmark$ Salah satu siswa dari perwakilan kelompoknya diminta maju ke depan kelas untuk membacakan isi yang terdapat dalam gambar tersebut

$\checkmark$ Siswa bergantian membacakan hasil diskusi sesuai kelompoknya masing -masing.

$\checkmark$ Salah satu siswa maju ke depan membaca, siswa yang lain memperhatikan. 


$$
\begin{array}{ll}
\text { Volume } & : 05 \\
\text { Nomor } & : 02 \\
\text { Bulan } & : \text { Mei } \\
\text { Tahun } & : 2019 \\
\text { http } & \text { ://ejurnal.pps.ung.ac.id/index.php/AKSARA/index }
\end{array}
$$

Setelah siswa membaca, kemudian guru membimbing siswa untuk duduk yang rapi kemudian siswa dan guru membaca bacaan secara bersama - sama

b.) Pertemuan kedua

(1) Mengawali pelajaran dengan berdoa setelah itu mengkondisikan kelas.

(2) Siswa dan peneliti bertanya jawab tentang keadaan setelah pulang sekolah.

(3) Menyampaikan tujuan pembelajaran yang akan dicapai.

(4)Membagikan lembar bacaan, siswa diminta membaca bacaan sesuai ucapan yang tepat.

(5) Siswa diminta maju ke depan, membaca bacaan sesuai ucapan yang benar.

(6) Siswa diminta maju ke depan, membaca bacaan sesuai urutannya.

(7)Secara bergantian siswa membaca, guru menilai, siswa yang lainnya mengerjakan lembar evaluasi.

(8) Siswa mendeskripsikan gambar, kemudian siswa diminta maju ke depan kelas membaca hasil diskusi bersama teman kemudian guru memberi bacaan, siswa diminta membaca.

Observasi

Selama pelaksanaan pembelajaran peneliti bekerja sama guru kelas untuk mengamati jalannya pembelajaran pada siklus I dengan panduan lembar observasi. Dari kegiatan observasi tersebut diperoleh gambaran tentang jalannya kegiatan belajar mengajar yang secara garis besar sebagai berikut :

a). Bagi Guru

(1). Sudah memberikan motivasi kepada siswa dengan baik.

(2). Dapat menyampaikan materi dengan baik, jelas dan tepat.

(3). Dapat mengarahkan siswa dalam menggunakan media pembelajaran dengan media gambar seri untuk membaca permulaan dengan sangat baik.

(4). Penuh perhatian terhadap seluruh siswa

b) Bagi Siswa

(1). Siswa aktif dalam kegiatan perkembangan membaca permulaan.

(2). Siswa mampu menjawab pertanyaan dari guru.

(3). Siswa memperhatikan penjelasan materi yang diberikan oleh guru.

(4). Rasa ingin tahu dan keberanian siswa cukup tinggi.

Refleksi

Berdasarkan hasil pengamatan dan hasil membaca permulaan siswa, guru dan peneliti berdiskusi dan melakukan refleksi sebagai berikut :

$\checkmark$ Hasil membaca siswa meningkat, siswa sudah terampil mencapai target Kriteria Ketuntasan Minimum (KKM).

$\checkmark$ Berdasarkan pengamatan dan analisis hasil membaca siswa maka guru dan peneliti sepakat untuk mengakhiri siklus tindakan dalam pembelajaran membaca permulaan.

Tabel 2

Data Nilai Pada Tes Siklus II 


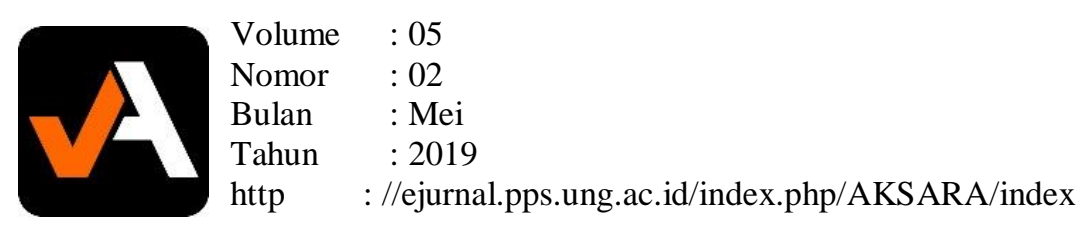

\begin{tabular}{|l|l|l|l|l|l|}
\hline \multirow{2}{*}{ No } & \multirow{2}{*}{ Nama Siswa } & Perolehan Nilai & \multirow{2}{*}{ Keterangan } \\
\cline { 3 - 5 } & & Pert. 1 & Pert. 2 & Rata-rata & \\
\hline 1 & Abd. Rahman Yusuf & 50 & 70 & 60 & T \\
\hline 2 & Aryo Tangahu & 50 & 70 & 60 & T \\
\hline 3 & Febriyati Ibrahim & 70 & 80 & 75 & T \\
\hline 4 & Moh.Agung Botutihe & 60 & 80 & 70 & T \\
\hline 5 & Moh.Dardha Lasori & 60 & 80 & 70 & T \\
\hline 6 & Refli Husain & 50 & 70 & 60 & T \\
\hline 7 & Adelin Batanga & 55 & 60 & 57,5 & TT \\
\hline 8 & Anastasya Febiyani & 60 & 85 & 72,5 & T \\
\hline 9 & Apriyanti & 50 & 70 & 60 & T \\
\hline 10 & Rahma Djau & 50 & 50 & 50 & TT \\
\hline 11 & Siti Fadilah Djau & 80 & 100 & 90 & T \\
\hline 12 & Ahmad Thalib & 70 & 100 & 65 & T \\
\hline 13 & Agung Tangahu & 70 & 95 & 82,5 & T \\
\hline 14 & Geplin Haleda & 80 & 100 & 90 & T \\
\hline Jumlah & 855 & 1110 & 962,5 & \\
\hline Rata - rata & 61,07 & 79,29 & 68,75 & \\
\hline Keterangan & Jumlah & & Prosentase & \\
\hline \multicolumn{2}{|l|}{ Tuntas } & 12 & 85,71 & \\
\hline Tidak Tuntas & 2 & 14,29 & \\
\hline
\end{tabular}

Dari data tersebut dapat dipahami bahwa setelah melaksanakan siklus II, siswa yang tuntas sebanyak sudah mencapai $85,71 \%$ atau 12 orang. Dari hasil penelitian pada siklus II, maka penelitian tidak perlu dilanjutkan pada siklus berikutnya. Namun guru harus terus melaksanakan bimbingan belajar untuk mempertahankan keaktifan dan partisipasi serta suasana dalam kelas sebagai tindak lanjut.

\section{PEMBAHASAN}

Berdasarkan hasil pelaksanaan pada siklus I dan II dapat dinyatakan bahwa pembelajaran Bahasa Indonesia menggunakan media gambar dapat meningkatkan hasil belajar siswa kelas I SDN 05 Wanggarasi, baik hasil belajar kognitif, afektif maupun psikomotorik.

1. Perkembangan hasil belajar afektif siswa sebagai berikut :

a. Siswa memperhatikan pelajaran dengan sungguh - sungguh.

b. Kemauan untuk menerima pelajaran dari guru meningkat.

c. Perhatian, minat, dan motivasi terhadap penjelasan guru meningkat.

d.Siswa aktif dalam pembelajaran.

2. Perkembangan hasil belajar psikomotorik siswa sebagai berikut :

a. Tidak ada siswa yang terlambat masuk kelas.

b. Menyiapkan kebutuhan belajar tanpa disuruh.

Dari hasil perkembangan belajar siswa dari segi afektif maupun psikomotorik, partisipasi siswa dalam pembelajaran meningkat. Mereka lebih banyak memperhatikan. Dengan partisipasi siswa yang aktif dan kreatif, suasana kelaspun menjadi lebih hidup dan menyenangkan. Keterampilan membaca pemulaan meningkat, yang tentunya berpengaruh terhadap keterampilan membacasiswa.

3. Perkembangan hasil belajar kognitif siswa. 


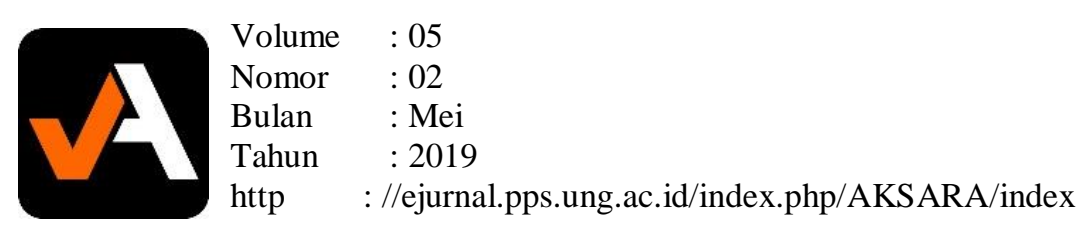

Pada siklus I setelah diadakan tes kemampuan awal dilanjutkan dengan siswa menerima materi membaca permulaan dengan mengidentifikasikan dan mendeskripsikan gambar seri. Proses pembelajaran disampaikan dengan strategi dan terencana dimulai dari kegiatan awal, inti dan penutup. Kegiatan ini terfokus mengaktifkan siswa mulai dari memperhatikan penjelasan, melakukan pengamatan untuk memperoleh kesimpulan.

Setelah dilaksanakan siklus I dan dievaluasi dapat dilihat adanya peningkatan hasil belajar siswa yaitu masih ada 6 orang atau 42,86\% dan siswa yang tidak tuntas sebanyak 8 orang atau $57,14 \%$. Sedangkan Siklus II merupakan lanjutan dari siklus sebelumnya untuk memantapkan dan mencapai tujuan penelitian. Pembelajaran yang disampaikan tentang membaca permulaan dengan indikator yang sama pada siklus I, namun diadakan peningkatan penggunaan media gambar yang digunakan. Hal ini bertujuan agar siswa lebih aktif dan antusias dalam pembelajaran.

Kegiatan belajar mengajar disampaikan dengan strategi terencana sebagaimana siklus I dan kegiatan pembelajaran dilaksanakan lebih optimal. Hasil siklus II menunjukkan peningkatan hasil belajar siswa yaitu siswa yang tuntas sebanyak sudah mencapai $85,71 \%$ atau 12 orang. Dari hasil penelitian pada siklus II, maka penelitian tidak perlu dilanjutkan pada siklus berikutnya.

Dari analisis data dan diskusi terhadap pelaksanaan pembelajaran pada setiap siklus, secara umum telah menunjukkan perubahan yang signifikan. Hal ini dapat dilihat dari perbandingan nilai terendah siswa, nilai tertinggi siswa, rata - rata kelas, dan siswa yang tuntas belajar dari tes awal hingga pada tes siklus II.

Berdasarkan data di atas dapat disimpulkan bahwa keterampilan membaca permulaan siswa dengan menggunakan media gambar pada siswa kelas I SDN 05 Wanggarasi mengalami peningkatan yang ditandai dengan peningkatan hasil belajar kognitif. Selain itu juga adanya peningkatan hasil belajar afektif maupun psikomotorik siswa.

\section{PENUTUP}

Berdasarkan hasil penelitian ini, penggunaan media gambar dalam pembelajaran bahasa Indonesia dapat meningkatkan keterampilan membaca permulaan pada siswa kelas I SDN 05 Wanggarasi Tahun 2014/2015. Hal ini dapat dilihat dari nilai rata - rata kelas terjadi peningkatan yaitu pada siklus I peningkatan hasil belajar siswa yaitu masih ada 6 orang atau $42,86 \%$ yang tuntas dan siswa yang tidak tuntas sebanyak 8 orang atau $57,14 \%$.sedangkan hasil pelaksanaan Siklus II siswa yang tuntas sebanyak sudah mencapai 85,71\% atau 12 orang. Dari hasil penelitian pada siklus II, maka penelitian tidak perlu dilanjutkan pada siklus berikutnya.

\section{DAFTAR PUSTAKA}

Abbas, Saleh. 2006. Pembelajaran Bahasa Indonesia yang Efektif di Sekolah Dasar. Jakarta: Departemen Pendidikan Nasional.

A.M, Sardiman. 2007. Interaksi Dan Motivasi Belajar Mengajar. Jakarta: Raja Gravindo Persada.

Anitah, Sri. 2009. Strategi Pembelajaran Di SD. Jakarta : Universitas Terbuka

Arsyad, Azhar . 2007. Media Pembelajaran. Jakarta: PT. Raja Grafindo Persada.

Darmiyati Zuchdi dan Budiasih. 2001. Pendidikan Bahasa Indonesia dan Sastra Indonesia di Kelas Rendah. Yogyakarta : PAS 


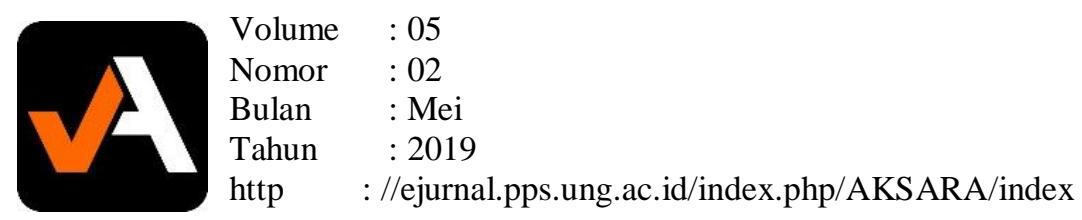

Dwi Sunar Prasetyono. 2008. Rahasia Mengajarkan Gemar Membaca pada Anak Sejak Dini. Yogyakarata: Think

Farida Rahim. 2008. Pengajaran Membaca di Sekolah Dasar. Jakarta: PT Bumi Aksara

Iskandarwassid dan Dadang Sunendar. 2008. Strategi Pembelajaran Bahasa. Bandung: PT. Remaja Rosdakarya

Iskandar. 2009. Penelitian Tindakan Kelas. Ciputat: Gaung Persada (GP) Press

Puji, Santosa. 2007. Materi dan Pembelajaran Bahasa Indonesia SD. Jakarta: Universitas Terbuka

Rini Utami Aziz. 2006. Jangan Biarkan Anak Kita Berkesulitan Belajar. Solo: Tiga Serangkai.

Rukayah. 2004. Membaca dan Menulis Permulaan dan Alternatif Membantu Siswa yang Berkesulitan. Surakarta: Universitas sebelas Maret

Soedarso. 1993. Sistem Membaca Cepat dan Efektif. Jakarta: Gramedia Pustaka Utama.

Tarigan, Henry Guntur. 1986. Membaca: Sebagai Suatu Keterampilan Berbahasa. Bandung: Angkasa.

Tampubolon, D.P. 1993. Mengembangkan Minat dan KebiasaanMemabaca pada Anak. Bandung: Angkasa. 